\title{
Central Scots Dialect in the East Lothian County: 2018 Morphosyntactic Dialectal Survey
}

Anthony R. Bour*

\begin{abstract}
The Scots language belongs to the Teutonic Germanic language family essentially spoken in the Lowland Scots area covering central and southern Scotland as well as the north-eastern part of the country. It is divided into four different groups of varieties, i.e. the Broad Scots dialectal group spoken in southern Scotland, the Doric dialect spoken in the north-eastern part of Scotland, the Insular Scots group spoken in the Shetland and Orkney Islands and the most spoken and written Scots dialectal group called Central Scots extending from the central western to the central eastern part of the country. The study carried out in the East Lothian county from 13 August to 21 August 2018 had the purpose to analyse the syntax and grammar of the local Lothian Scots and to determine if it still survives in the pervasive wave of Standard England English. A semistructured type questionnaire was distributed to 17 people during this period revealing a radically different grammatical attitude from the other enquiries conducted in the Scottish Borders five years earlier.
\end{abstract}

Key words: vernacular modals, morphosyntax, semantics, Scots dialects, combinations

* Hermann Paul School of Linguistics; bour.anthony1@orange.fr 


\section{Scots: Short Historical Introduction \& Dialect Labels}

The Scots language comes from a group of north-western Germanic dialects spoken by the Anglo-Saxons who landed in the south-eastern part of England in 449 A.D. The Saxons occupied the southern and western parts of Britannia while the Anglians colonised the central and northern areas of the country that had already been in the possesion of the Romans but had also been inhabited by the Celtic tribes: "The Saxons kept mostly to the south and west, as all the areas with -sex in their names still attest, while the Angles spread northwards through Yorkshire and Northumberland." (Murison 1977, 1). The Anglians reached the north-east of England in 547 and created the kingdom of Bernicia which allowed them to conquer the fortress of Din Eidyn in 638. Nevertheless, Scotland at the time was dominated by Celtic languages (Goidelic and Brythonic dialect groups) and only a small geographical area located in the south-east of Scotland was inhabited by Anglians. By the end of the 7th century, Great Britain was composed of seven kingdoms called the Heptarchy, two of which, named Mercia and Northumbria, represented the two largest kingdoms put into place by the Anglians. The Scots language is the direct descendent of the Mercian and Northumbrian dialectal groups brought by these people. The rise of this language in Scotland actually starts when King Malcom III (1057-1093) generates a series of sweeping reforms to strengthen the monarchy by reorganising it on Anglo-Norman lines. Allowing other groups, including the Normans, the French, and the Dutch to grant Scottish territories via the implementation of the Burghs gives the Scots language the opportunity to extend beyond the south-eastern area. Most business activities taking place between Germanic kingdoms are mostly derived from Anglo-Saxon rules. Malcom III's son, David I (1124-1153) remains the main and the most efficient instigator of these profound changes, which gives a definite boost to Scots as a powerful national language in the sectors of commerce, justice, administration, and religion until the Reformation period in 1560 .

The Scots language as we know it has not always been called Scots. Over the past 1,500 years, there have been diverse appellations, the first of which are termed Anglic (McClure 1979, 27), Inglis (McClure 1998, 10), Englisc (McClure 2002, 7) or Angelisc (Warrack 2000, 5). Different spelling variants for a same language entity were used due to the Anglian invasions in northern Britain during the Old English period. There was the Scots language referring to Scots Gaelic or also called the Ersche language due to its Irish roots and the Inglis language having north-western German roots. From the 15th century onwards, two main writers Adam Loutfut and Gavin Douglas desired to change the name of their language to show their cultural and linguistic differences with the Saxon area: "Adam Loutfut in 1494 is apparently the first to name it Scottis. Gavin Douglas in the General Prologue to his Eneados stresses the distinction between 'our 
awin language' which is Scottis, and the language of England, which he calls Inglis or Sudron." (McClure 2002, 44)

From the 17th century onwards, the term Scots was eventually applied to identify the Germanic language Inglis as opposed to Scottish Gaelic representing the Celtic language of Scotland.

Nowadays, Scots and English are often mixed up which gives a "Scottish-English dialectal continuum” as Fiona Douglas (Kachru \& Nelson 2009, 45) calls it:

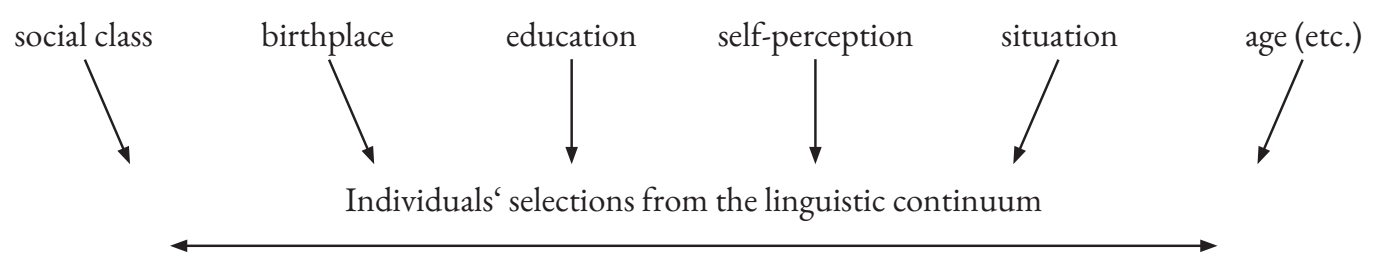

Dense/Broad/Dialect Scots (SC)

E.g., the Doric, Glaswegian.

Distinctive local vocabulary, grammar and strong local accent.

Generally used by working-class Scots.
Scottish Standard English (SSE)

Much closer to Standard English.

Limited Scottish grammar, vocabulary and idiom, but still with Scottish accent.

Used by middle-class Scots and by working-class Scots in formal situations.

Figure 1: Scottish-English dialectal continuum from Douglas $(2009,45)$.

Extralinguistic factors inside the Lowland Scottish society generate a great number of state-of-the-art Scottish-English (SE) varieties ranging from Dense or Thick Scots (SC) corresponding to traditional local or regional low anglicised dialects to Thin or Standard Scottish English (SSE) corresponding to mainstream highly anglicised Scottish English varieties containing very few Scots words and in which the difference is mainly phonological. All these dialect groups are termed Scots English by McArthur (1979, 59). For some Scottish respondents, the important influence of English degraded the Scots language in its entirety and thus they do not consider it as a language any more, as Douglas asserts: "However, Scots are also plagued by linguistic insecurity, and perhaps, the majority regard their language as being bad English or slang rather than Scots." (Douglas 2009, 48)

As regards some linguists, they adopt a softer approach in the contemporary identity of SC and SE: "McArthur's (1987) circle of World English places SC on a par with SE as a variety of British English whereas Görlach's (1990) circle places SE alongside EnglishEnglish, Welsh English, and Irish English as a variety of British English, but isolates SC 
outside the circle with varieties such as Anglo-Romani and Tok Pisin, thus emphasizing the discreteness of SC from SE.” (Douglas 2009, 48)

The results of the dialectal enquiries carried out in the Scottish Borders from 2010 to 2013 have led more to the left side of the continuum, i.e. the Dense Scots dialects (Bour, 2015, 2017, 2018). The situation in the East Lothian county is quite different and the way people speak and write their dialect(s) is more located on the right side of the continuum, i.e. Mainstream Standard Scottish English(es).

\section{Dialectal Enquiry: Questionnaire Survey}

This was a semi-structured questionnaire containing both closed, semi-closed, and open questions distributed randomly in four towns of the East-Lothian county: Dunbar, North Berwick, Haddington and Musselburgh. It was both equally important to know the level of knowledge of the current Scots spoken by the respondents and to ask them what they think of this language. Some of them clearly demonstrated their personal approach to Scots and its role in their society. The questionnaire contains 3 tasks. Tasks 1 and 2 are the syntactic parts. Task 1 consists of changing mainstream Standard English structures into a Scottish-English variety or a more traditional Scots dialectal structure. In Task 2, a list of modal combinations is proposed, and it is up to the respondents to decide if some or all of them can be negated or inverted. Double and triple modals are combinations that are occasionally found in Broad Scots grammar notably in the local Hawick Scots dialect. This enquiry also has the purpose of determining if this Multiple Modality system is also found in other Lowland territories. The last task is composed of 13 questions most of which deal with the respondents' frequency of use of Standard English, vernacular Scots, and Scottish English on a daily basis. Sociological variables are also part of the questionnaire in order to determine the places where the Lothian respondents use their Scots (-English) varieties. Two tables sum up these variables. The first one lists ten Standard speakers while the second one is focussed on the vernacular speakers. 


\begin{tabular}{ccccccc}
\hline Gender & Age & Social Class & Occupation & Place of birth & Place of residence & Workplace \\
\hline M & 21 & MC & Museum assistant & London & Gifford & Dunbar \\
M & 77 & & Retired & & Dunbar & Dunbar \\
F & 20 & MC & Shop assistant & Haddington & Haddington & Haddington \\
F & 21 & & Sales assistant & Sussex & North Berwick & North Berw \\
F & 33 & & Shop assistant & Edinburgh & Haddington & Haddington \\
F & 50 & & Shop owner & Glasgow & North Berwick & North Berw \\
F & 55 & MC & Interior designer & Edinburgh & North Berwick & North Berw \\
F & 56 & & Shop assistant & Bolton & Haddington & Haddington \\
F & 56 & & Shop owner & Edinburgh & Haddington & North Berw \\
F & 56 & & Wool worker & Lancaster & Coldingham & Coldingham \\
\hline
\end{tabular}

Table 1: Respondents using neither Scots dialects, nor vernacular Scottish English varieties (Tasks $1 \& 2$ ).

\begin{tabular}{ccccccc}
\hline Gender & Age & Social Class & Occupation & Place of birth & Place of residence & Workplace \\
\hline M & 23 & MC & Store manager & Tripoli & Edinburgh & Edinburgh \\
M & 48 & MC & Office worker & Edinburgh & North Berwick & Edinburgh \\
M & 51 & WC & Shop keeper & Musselburgh & Port Seton & North Berw \\
M & 70 & & Retired & Newtongrange & Dunbar & Dunbar \\
M & 76 & & Bookshop dealer & North berwick & North Berwick & North Berw \\
F & 58 & & Retired & Rosewell & Dunbar & Dunbar \\
F & 61 & WC & Community & Haddington & Dunbar & Dalkeith \\
& \multicolumn{7}{c}{ worker } \\
\hline
\end{tabular}

Table 2: Respondents using vernacular Scots and Scottish English dialects (Tasks $1 \& 2$ ).

Blank spaces imply that the respondent did not want to reveal this information. Those who indicated that they belong to the middle class have employments related to the fields of business, architecture, and cultural history.

Furthermore, some additional questions deal with the label concept to know if some respondents give a specific name to their idiolect, local or regional dialect(s) (Task 3, Questions 5, 7 \& 13). 


\section{Questionnaire, Task 1: Vernacular Continuum of the Scots Syntax}

It was not an easy task to find people in the four towns who speak Central Scots because Standard England English is nowadays present everywhere in the county. The table below confirms the current situation:

\begin{tabular}{lcc}
\hline & Yes & No \\
\hline Do you speak Scots? & 8 & 9 \\
Do you write Scots? & 1 & 16 \\
\hline
\end{tabular}

Table 3: Number of respondents who speak and/or write Scots.

Fortunately, 7 out of 17 informants still speak a part of the Central Scots dialect. Since they do not all have the same fluency in the way of using the dialect, it is very useful to take Fiona Douglas' Scots-Scottish English dialectal continuum into account when analysing the first task of the 17 questionnaires.

Ten standard sentences compose the first task:

(1) It is possible that he has to see her tonight.

(2) Ian can probably repair his uncle's car.

(3) She's bound to win the race. I am quite certain that she is capable of doing it.

(4) Formerly, John was outgoing and could help many people in the community.

(5) Perhaps it would be best for him to go now.

(6) The neighbours should probably come around about this common project.

(7) Katia will be able to join them in Italy by next week.

(8) She came down with the flu. She shouldn't be allowed to go out. She could infect other people.

(9) Maybe this couple used to be able to run the marathon in less than 10 hours.

(10) Personally, I think you ought to rest.

Among the seven respondents, five of them use a limited number of Scots words in some of their English sentences. However, the spelling belongs to the Central Scots dialect. Here are their slight modifications. None of them changed sentence (4):

(1) It is possible that he has to see her the night.

Ken you see her the night. 
He'll possibly see her the night.

He might see her the night.

Does he hae tae see her the night?

(2) Ian ken repair his uncle's car.

(3) I ken she kin da that.

She's bound tae win her race. She's mair than capable ae winning.

(5) Perhaps it would be best ta go now.

He better go noo.

Get rid $o$ ' him.

(6) The neighbours should probably come roond the noo.

The neebors should get the gither for this project.

We shid get everyone the gither.

(7) Katia's goan oot with them to Italy next week.

(8) She caught the flu. She shouldny be allowed to go oot. She could infect people. She came doon wi the flu. She shouldnae be allowed oot. She could pass the flu on.

She's no well. She isnae allowed oot. She'll spread it.

She came down wi the flu. She should nae be allowed tae go out.

(9) Maybe this couple used to could run the marathon in less than 10 boors.

Maybe this couple used to be able to run the marathon in less than 10 oors.

Maybe this couple used tae be able to run the marathon in less than 10 hours.

Sit yersel doon. (No explanation provided for this transformation)

These syntactic transformations towards the Central Scots are limited. If we use Douglas' dialectal continuum, these sentences are located at the right of the continuum in which there is the presence of a strong anglicisation of the Scots idiom. This Scots is thin. Thus, they are not far away from Standard Scottish English. Some Scots words are repeated several times by the five informants such as: tae, nae, oot, doon, ken and wi. It is interesting to notice that ken replaces two English words, i.e. the modal auxiliary can in sentences 1 and 2 as well as the main verb know in sentence 3 . To make the difference, one informant replaced can by kin in this third clause. Noun phrases were occasionally written in Task 1 such as the night, the gither and the noo. All these words and noun phrases are quite mundane in many Scots varieties. Scottish people who have learned a few basic Scots words since their childhood have generally acquired this type of spelling and lexicon. Although they have a limited knowledge of the dialect of their forbears in this county, they are still identified as bidialectal people, with Standard England English 
or also termed Standard South-Eastern English being the dominant dialect in their daily talks. This is mainly a spelling difference; the grammar being constructed on the Normative English grammatical system. There is just one exception in which one respondent proposed a typical southern Scots structure called a Double Modal: used to could. This is a complex combination composed of a marginal modal in first position followed directly by a central modal in second position, which is impossible in Standard Englishes. The second element can only be an intermediate modal expression, i.e. a quasi or semi modal such as be able to, be going to or have to (Quirk 1985, 137) in Normative English varieties.

The other two respondents, a 51-year-old man and a 61-year-old woman indicated more typical Central Scots and Broad Scots constructions respectively in this first task. Both belong to the working class. They partly turned the ten sentences into these two Scots varieties. Here are their interpretations:

(1) He might bae tae see her the night. (51-year-old man) He might buv ti see 'ur the night. (61-year-old woman)

(2) Ian wid be able tae repair his uncle's car, mibey. Ian 'ull likely fix is uncle's motor.

(3) She's bound tae win the race. Am share she could dae it. She'll win the race awright. Am shair she's up ti it awright.

(4) John wis outgoing and used tae help many people in the community. A'fore this, John wis aye oot, and helpin' folk roond aboot.

(5) Mibbe it wid be best fer him tae gaun noo. Mibi it wid better for him ti gaun.

(6) The neighbours might come roond tae this common project. Awbody roond about should git the gither on this.

(7) Katia will be able tae jine them in Italy by next week. Katia will manage ti meet thum in Italy bi next week.

(8) She got the flu. She shouldnae be allowed tae gaun oot. She could gie it tae other folk.

Shi came doon wi flu. Shi shoodni be oot. Shi could $g i$ it other folk.

(9) Mibbe this couple used tae be able to run the marathon in less than 10 hours. Mibi this twa yist ti be able $t i$ run the marathon under 10 oors.

(10) Personal, I think ye should rest. For me, $a$ think yi shood be in yer bed.

The female respondent provided more Broad Scots sentences, which is evident in the spelling of some words like $t i, s h i, g i, m i b i$, shoodni, bi, yist and $y i$ instead of the Central 
Scots and English equivalents indicated by the male informants, i.e. tae, she, gie, mibbe, mibey, shouldnae, by, used and ye. Broad Scots, especially the one from the Hawick local area, contains this kind of spelling with $i$, which is only found in a column called "The Westender" written from 2009 to 2011 in the local newspaper of the town:

a) Mibee they kent they couldni compete wi a plain loaf, especially toasteed. (The Westender, 16 April 2010)

b) It wadni hev mittered if a volcano hed erupteed for Nichols wad've got ee where ee were gaun. (The Westender, 23 April 2010)

c) The volcano in Iceland isni the only 'hing blawn hot air the now, eh no? (The Westender, 23 April 2010) The female respondent uses a Thick Scots variety and therefore it is less anglicised and mixed than the male respondent's dialect.

The female respondent uses a Thick Scots variety and therefore it is less anglicised and mixed than the male respondent's dialect.

\section{Questionnaire, Task 2: Where is Multiple Modality?}

Although the Scottish Borders region and the East-Lothian county are close to each other, the respondents living in these two areas of the Lowlands do not adopt the same attitude towards Multiple Modals. These are combinations of two or three adjacent modals, a grammatical system that is not accepted in Standard British and American English grammars. It is not possible to generate any types of combinations. It is a matter of syntactic and semantic ordering which determines the meaning of the entire sentence. In the questionnaire survey, I propose twelve sentences containing ten Double Modals (DMs) and two Triple Modals (TMs). They can be classified into four categories (Quirk, 1985, 137):

1. Core Double Modals

These combinations are exclusively made up of Central Modals (CMs): (maun could, wad coud, might could, may will, ll can, might will, may can)

2. Hybrid Double Modals

These combinations are made up of a Central Modal and an intermediate modal expression such as a Marginal Modal (used to, ought to) or a Semi Modal (be going to). MMs are positioned before or after SMs in the syntactic ordering: (used to could, should ought to, used to wid) 
It also depends on the type of combination used, i.e. any hybrid combinations having used to in its structure will in the majority of cases imply an $M M+S M$ syntactic ordering, which is not the case if ought to is present in the hybrid modal sequence.

3. Exotic Core Triple Modals

These combinations are made up of three Central Modals:

(will should can, will might could)

In general, they have a lower degree of frequency than Core DMs.

4. Exotic Hybrid Triple Modals

These combinations are made up of Central Modals and other non-classical modal expressions:

(will need to can, might used to could, should might better)

Any of the Multiple Modals of these categories can be written with one or several Scots spelling variants belonging to unique Lowland dialects. It will not modify the meaning of the clause.

The purpose of this second task is to turn each combination into a negative and interrogative syntactic form. Contrary to the Scottish Borders, the Multiple Modality system is barely used in the East Lothian because only one respondent out of 17 maintained two core Multiple Modals only in the negative. The 61-year-old respondent from Dunbar proposed the following interpretations:

(3) She widny cond milk the kye gin she ettelt.

$$
\text { E R }
$$$$
\text { M1 M2 }
$$

(4) We might no cun park over there.

E R

M1 M2

The position of the negator is important in the Multiple Modality system. In Vernacular Scots and Scottish-English dialects, the Scottish or English negative adverb is almost always positioned between the first and the second modal. If the negator is attached to M1, this is what Keith Brown $(1991,81)$ calls a sentence wide-scope negation, meaning that the entire clause is negated. The situation varies when the negator is detached from M1, it therefore leads to a narrow-scope negation, i.e. only a part of the clause is negated. 
Furthermore, with this type of core DM, we are dealing here with an Epistemic-Root semantic ordering which gives the following paraphrases:

$\left(3^{\prime}\right) \quad$ It would be impossible for her to be able to milk the cow if she tried.

$\left(4^{\prime}\right) \quad$ It is probable that we are unable to park over there.

In sentence 3), the negation is connected to the matrix clause while in sentence (4) the negation moved and is therefore connected with the subordinate clause.

In the other sentences, only one modal auxiliary was maintained with a detached or attached Scots negative by the 61-year-old respondent, which include the following:

(5) Lance might no want corn instead of potatoes.

(6) He no cun come the morn.

(7) You shoodni make the rules clear.

Only the first two sentences were turned into the interrogative-negative form:

(1) Was it no him that couldny drink black coffee late at night?

(2) Couldy no muck the byre?

She always indicates a Scots dialectal structure and diverse Scots orthographies even if some clauses are exclusively written with the English spelling. She is an exception among the 17 respondents. The majority barely completed this task due to their very low level of knowledge of the Scots language. They neither recognised nor understood any of the proposed combinations. Only two additional informants also indicated Scots elements but neither of them maintained a DM or a TM. Here is what they wrote:

Responses of a 51-year-old male respondent from Port Seton.

(1) Could he no yince drink black coffee late at night? He used tae no be able to drink black coffee late at night.

(2) Could the laddie no muck oot the byre? The laddie couldnae muck oot the byre.

(3) Could she milk the coo if she tried? She couldnae milk the coo if she tried.

(4) Could oo no park ower yonder?

(5) Wid Lance want corn insteid o tatties? Lance might no want corn insteid o tatties.

(6) Could he no come the morn? 
(7) Should ye no make the rules clear?

Ye shouldnae make the rules clear.

(8) Could she no tend tae that bairn?

She cannae tend tae the bairn.

(9) Could oo no bae time tae eat somethin afore oo hae tae gaun?

Oo wullnae bae time tae eat something afore o bae tae gaun.

(10) Can A mibbey get it oot the morn?

(11) Did he no used tae let me up the brae?

He didnae used tae let me up the brae.

(12) Wid they no hae tae drive a lorry tae get thon job?

They deb need tae drive a lorry tae get thon job.

He is the only respondent who completed almost the entire task. By looking at the questions he made, there is a clear preference for the second modal identified in the combinations as could and can in 8 sentences. The type of combinations did not have an impact on the choice of the modal. Can and could in these 8 sentences are root modals expressing ability. This remains the most adapted meaning for this respondent when generating Yes-No Questions in Central Scots. Nonetheless, both modals are only present three times, couldnae (twice) and cannae (once), in negative sentences. Regarding the negators, the respondent proposed two types of Scots negative adverbs based on the type of sentence i.e. the integration of the narrow scope negator no in questions whereas this is the attached wide scope negator nae inserted in negative sentences. No is a more flexible negator than nae because it can be found in both interrogative and negative syntactic forms. There is no observation of nae in questions in contemporary Scots dialects. Used tae in sentences 1 and 11 has two different grammatical identities. In the first sentence, used tae is identified as a modal auxiliary due to the position of the narrow-scope negator right after the modal. The grammatical nature changes in the eleventh sentence in which used tae is a verbal form due to the presence of the primary auxiliary do in the past located before used tae. This time the Central Scots negator nae was proposed by the respondent and attached to the Primary Auxiliary. Eventually, the very last sentence written by the respondent contains a unique local Hawick word deb (Dietz-Verrier 2003, 87) replacing the primary auxiliary do and the negator not. This is a lexical levelling process that can occasionally be found in Scots dialects. 
Responses of a 58-year-old female respondent from Dunbar.

(1) He canny drink black coffee at night.

(2) The laddie couldnae muck the byre.

(4) We cannae park o'er there.

(5) Lance'll want corn instead o' tatties.

(6) He should be there the morn.

The female respondent indicated a limited number of morphosyntactic transformations in five of the twelve Scots and Scottish-English sentences. She only brought modifications in the negative in three sentences. She never turned them into questions. Furthermore, she has a basic knowledge of Central Scots and combines a few Scots words with Standard English quite often. She maintained the second modal in sentences (1), (2), and (4) accompanied by two types of Scots sentential negators nae and ny and she never uses the Multiple Modality system. The rest of the sentences was not modified by the respondent.

Many fewer respondents decided to complete this second task of the questionnaire in great part because it contained a welter of DMs and TMs barely known and considered as peculiar by the local population of these four towns. Nonetheless, these three respondents still demonstrated a solid ability in using the Central Scots dialect essentially in the spoken medium. Despite the significant increase of dialect mixing of Scots with Standard England English, an interesting list of morphological words and expressions continue to survive in the mainstream anglicised East Lothian county.

\section{Questionnaire, Task 3: What is Scots for them?}

\subsection{Defining Scots}

As seen previously, the Scots language is in a fragile state in the East Lothian county. The third task contains 13 questions, one of which asked the respondents what they think of Scots. What does it represent to them in the 21st century? Is it still connected to their culture and identity or has it become moribund? Regarding the respondents who continue to use a part of Scots, two of them indicate that Scots is a colloquial language and they exclusively speak it at home and with friends, typically in non-working environments. Another informant writes Standard English with a correct grammar and syntax, but he never writes a Scots word. English is a written system unlike Scots being a spoken system. For two respondents, Scots is still identified as a dialect and English as 
a language. They indicate the separation between the language and the dialect and do not consider Mainstream England English as a Standard variety.

Those respondents who essentially use Standard English propose a spectrum of definitions of Scots. For two respondents, it is still identified as a traditional dialect representing the beginning of a civilisation with unique traditions only spoken by the locals. Two other respondents assert that Scots is an old language on the wane, essentially used when working on literature and Burn's poems. Only a very limited number of sociocultural expressions can be spoken and written in modern Central Scots. It is no longer a full and stable language. For most respondents, Scots just represents a limited series of words integrated into (Scottish) English. The label Scottish English that some of them proposed to define their dialect refers to the right end of Douglas's dialectal continuum mentioning Standard Scottish English (SSE) instead. SSE is identified as Standard England English with diverse Scottish accents. There is no presence of Scots syntactic or lexical structures. Finally, only one respondent defines Scots as a clinically dead language.

\subsection{Scots Dialect Labels}

Among the seven informants who have some knowledge of the Scots language, four of them proposed a name to their dialect they use on a daily basis. This is what they indicated:

a) We just refer to it as Edinburgh dialect

b) Broad Scots

c) Local slang

d) I use Lowland Scots with Berwickshire/Borders emphasis

Respondents in b) and d) are the only ones who completed all the tasks of the questionnaire with quite a lot of vernacular data. They both indicated the variety of Scots essentially used in the south-eastern part of Scotland. Unlike the respondent in b), the other one actually uses traditional Southern Scots features, such as shoodni \& ti, commonly spoken in the Scottish Borders region in which the Berwickshire county is located. The respondent in b) constantly wrote Central Scots features such as shouldnae \& tae. It means that he does not make any difference between both Scots varieties. Concerning the other appellations in a) and c), they wrote a couple of typical Central Scots words in sentences that remain strongly anglicised. The label Edinburgh Scots is very close to Standard Scottish English in Douglas's dialectal continuum. Only one respondent preferred to call it a slang probably considering that what is vernacular cannot belong 
to the standard language system. Concerning the other respondents who did not indicate any Scots forms, only one of them mentioned the term Anglicised Scots meaning that she speaks Scottish Standard English. Only the accent is slightly modified which corresponds to the extreme end of the dialectal continuum.

\subsection{Frequency of Use}

As can be seen in table 4, people are accustomed to using the Scots language in the spoken medium. Nevertheless, four standard speakers also indicate that they use Central Scots occasionally. It means that they use mainstream English grammar with a Scottish accent. The syntax, the lexicon and the spelling remain completely Standard English. There is no difference between Scots and SSE for these respondents. In addition, the respondents who use vernacular Scots barely write it. There are a great number of Scots spelling variants and some Scottish citizens no longer know how to write their Scots variety they have spoken since their childhood. The frequency results are indicated below:

\begin{tabular}{lccccc}
\hline & A lot & Often & Occasionally & Rarely & Never \\
\hline Oral frequency of Scots & 1 & 4 & 6 & 2 & 4 \\
Written frequency of Scots & 0 & 0 & 0 & 7 & 9 \\
\hline
\end{tabular}

Table 4: Frequency of use of the Scots language.

\subsection{Social Contexts}

The respondents give different identities to Scots and Scottish English dialects and it is to be noticed that the same locations in the use of both types of dialects are regularly selected by vernacular and standard speakers. The spoken frequency of use always remains more important than the written frequency of use. For example, vernacular speakers of Scots and Scottish English get used to speaking Scots at home and prefer using them in writing at work. This type of employment can be related to sectors of manual work. In social events taking place in the streets, in pubs or clubs, Scots and Scottish English dialects are spoken by a minority of Lothian respondents. This oral vernacular Scots grammar is easier to use for these respondents most of whom do not know the spelling system of modern Central Scots words. Regarding Standard Scottish speakers, they both identify these two labels Scots and Scottish English as Standard Scottish English varieties in which only the pronunciation is slightly modified. The majority uses standard varieties when being in non-working contexts with friends and family. One respondent indicated a strict use of anglicised Scots only during Burns' Night and other 
activities related to the famous Lowlands poet and Scottish national bard Robert Burns (1759-1796). Only one respondent uses Standard Scottish varieties outside the East Lothian county.

\section{Conclusion}

The survival of the Scots language in its mixed and traditional forms is conspicuously in a very fragile state. It is henceforth considered by the majority of the Scottish population in the East Lothian county as a dormant or dead idiom. Scots in this Scottish territory is located on the extreme right side of Douglas' dialectal continuum, in which, phonologically speaking, just a hint of Scots is used among most inhabitants in what is termed the Scottish Standard English dialect spoken in numerous sectors of the East Lothian county. However, the dialectal survey showed that there is still an exceptional minority of respondents who speak more or less anglicised varieties of Scots and who know the spelling systems of these dialects when writing, for example, in Modern Central Scots or in more traditional Broad Southern Scots. The final table below indicates the labels of the Scots varieties that these respondents use in this county everyday.

\begin{tabular}{lccc}
\hline & SED & SD & EED \\
\hline In your daily life, you use more & 10 & 2 & 5 \\
\hline
\end{tabular}

Table 5: Variety labels from Scots to English.

Scottish English Dialect (SED) is the most logical choice for 10 out of 17 respondents who participated in the survey because it corresponds both to the group of Thin Scots varieties in which Standard England English is dominant and to Central Scots dialects identified as the most spoken and written varieties in Lowland Scotland. Dense Scots which was only selected by two people regroups all the traditionally least anglicised Scots Dialects (SD) mostly spoken and written in Southern Scotland. Five respondents selected the label English English Dialect (EED) to clearly emphasise that they never use a single syntactic, lexical, spelling and phonological feature of Scots in their daily speech. It is necessary to determine if this current dialectal situation will be repeated in the other two counties of the Lothian region, i.e. Mid and West Lothian? The Scottish Borders field surveys showed that significant differences appear from county to county in the use of vernacular grammatical features and that opinions regarding the regional language 
can be quite radical among respondents from a single town. In the near future, field linguistics prospects in the remaining Lothian regions will be conducted to describe and analyse the degree of importance of Scots dialects in their syntactic and lexical aspects in this highly economic central eastern part of Lowland Scotland.

\section{Abbreviations:}

\section{SE: Scottish English}

SC: Scots

SSE: Standard Scottish English or Scottish

Standard English

SED: Scottish English Dialects

SD: Scots Dialects

EED: English English Dialects

MC: Middle Class

WC: Working Class
M: Male Informant
F: Female Informant
DM: Double Modal
TM: Triple Modal
MM: Marginal Modal
SM: Semi Modal
E: Epistemic
R: Root

\section{References}

Battistella, Edwin. 1991. “The Treatment of Negation in Double Modal Constructions.” Linguistic Analysis 21: 49-65.

Battistella, Edwin. 1995. “The Syntax of the Double Modal Construction.” Linguistica Atlantica 17: 19-44.

Beal, Joan. 1993. 'The Grammar of Tyneside and Northumbrian English'. In Real English: The Grammar of English Dialects in the British Isles, 4, edited by James Milroy and Lesley Milroy, 99-138. Longman Group UK Limited.

Bour, Anthony 2015. "Exotic Multiple Modals: Morphology and Syntax.” Scottish Language: 14-41. http://www.arts.gla.ac.uk/scotlit/asls/ScotLang.html

Bour, Anthony. 2017. "Negated and Inverted Syntax of Modal Combinations in the Scottish Borders: Traditional Double Modals, Hybrid Double Modal and Exotic Triple Modal.” Scottish Language: 21-53. http://www.arts.gla.ac.uk/scotlit/asls/ScotLang.html

Bour, Anthony. 2018. "The Multiple Modality system in Southern Scotland: Level of Acceptability of Double and Triple Modals in the 21st Century Scottish Borders Region.” Colloquium: New Philologies 3 (2): 1-26. https://colloquium.aau.at/index.php/Colloquium/ issue/view/5

Brown, Keith and Millar Martin. 1979. “Tag Questions in Edinburgh Speech.” Linguistische Berichte 60: 24-45.

Brown, Keith, and Martin Millar. 1980. "Auxiliary Verbs in Edinburgh Speech.” Transactions of the Philological Society: 81-133. 
Brown, Keith, and Jim Miller. 1982. "Aspect of Scottish English Syntax." English World-Wide 3: 3-17.

Brown, Keith. 1991. "Double modals in Hawick Scots." In Dialects of English Studies in Grammatical Variation, edited by Peter Trudgill and Jack Chambers, 74-103. Harlow: Longman Group UK Limited.

Calvet, Louis Jean, and Pierre Dumont. 1999. L'Enquête Sociolinguistique. L'Harmattan.

Chomsky, Noam. 1957. Syntactic Structures. Mouton, The Hague.

De-La-Cruz, Juan. 1995. "The Geography and History of Double Modals in English." Folia Linguistica Historica XVII/1-2: 75-96.

Dietz-Verrier, Christian. 2003. Linguistic Situation and Language Attitudes in Hawick/Scottish Borders, an Empirical Study. Master's thesis, Grin Publishing.

Douglas, Fiona. 2009. "English in Scotland." In The Handbook of World Englishes, edited by Braj Kachru, Yamuna Kachru and Cecil Nelson, 41-57. Hoboken. Wiley Blackwell.

Macafee, Caroline. 1980. Characteristics of Non-Standard Grammar in Scotland. http://www. abdn.ac.uk/ en1038/grammar.html

McArthur, Tom. 1979. "The Status of English in and Furth of Scotland." In Languages of Scotland, 50-67. W \& R Chambers Ltd.

McClure, Derrick. 1979. “Scots: Its Range of Uses.” In Languages of Scotland, edited by Tom McArthur and Jack Aitken, 26-48. W \& R Chambers Ltd.

McClure, Derrick. 1998. "What is the Scots Language?” In The Scots Language, Its Place in Education, edited by Liz Niven and Robin Jackson, 7-18. Riley Dunn \& Wilson Ltd.

McClure, Derrick. 2002. Doric, The Dialect of North-East Scotland. Varieties of English Around the World. Amsterdam: John Benjamins Publishing Company.

McClure, Derrick. 2002. "Scottis, Inglis, Suddroun: Language Labels and Language Attitudes." In Scots and Its Literature, edited by Derrick McClure, 44-56. Amsterdam: John Benjamins Publishing Company.

Miller, Jim. 1993. “The Grammar of Scottish English.” In Real English, The Grammar of English Dialects in the British Isles, edited by James Milroy and Lesley Milroy, 99-138. Harlow: Longman Group UK Limited.

Murison, David. 1977. The Guid Scots Tongue. Edinburgh: William Blackwood.

Nagle, Stephen. J, and Michael Montgomery. 1994. "Double Modals in Scotland and the Southern United States: Trans-Atlantic Inheritance or Independent Development?” Folia Linguistica Historica XIV/1-2: 91-107.

Nagle, Stephen. J. 1995. “English Double Modals: Internal or External Change?” In Linguistic Change Under Contact Conditions, edited by Jacek Fisiak, 207-215. Berlin: Mouton de Gruyter.

Nagle, Stephen J. 1997. "What is Double About Double Modals?" In Language History and Linguistic Modelling, edited by Raymond Hickey, 1513-1526. Trends in Linguistics, Studies and Monographs (Book 101), De Gruyter.

Quirk, Randolph, Sidney Greenbaum, Geoffrey Leech, and Jan Svarvik. 1985. A Comprehensive Grammar of the English Language. London: Longman. 
Rennie, Susan, Matthew Fitt, and Barbara Robertson. 1999. Grammar Broonie: A Guide tae Scots Grammar. Edinburgh; Edinburgh University Press.

Visser, F. Theodorus. 1963-1973. An Historical Syntax of the English Language. Leiden: Brill. Warrack, Alexander. 2000. The Scots Dialect Dictionary. Glasgow: Waverley Books Ltd. 


\section{Appendix: Questionnaire Model}

\section{Dialectal survey (Scots dialects, Scottish English dialects): Grammatical features used at present in the Lowland Scots area}

Last Name:

Christian Name:

Age:

Social class:

Job:

Town in which you were born:

Town in which you live:

Town in which you work:

Indicate the time you spent to complete the questionnaire:

VERY IMPORTANT!: Use your own dialectal knowledge, your own syntax and grammar. Do not use any dictionaries or grammar books to complete this questionnaire. Fill it in on your own without the help of anyone. Complete as much as you can. Thank you in advance for respecting these rules and for your cooperation.

\section{Task 1}

Translate the following sentences into Scottish English and/or into Scots.

1.) It is possible that he has to see her tonight.

2.) Ian can probably repair his uncle's car.

3.) She's bound to win the race. I am quite certain that she is capable of doing it.

4.) Formerly, John was outgoing and could help many people in the community.

5.) Perhaps it would be best for him to go now.

6.) The neighbours should probably come around about this common project.

7.) Katia will be able to join them in Italy by next week.

8.) The came down with the flu. She shouldn't be allowed to go out. She could infect other people.

9.) Maybe this couple used to be able to run the marathon in less than 10 hours.

10.) Personally, I think you ought to rest. 


\section{Task 2}

Turn each of the underlined structures into the negative and into questions. You do not have to write the entire sentence again. However, if you wish to make additional modifications as regards the words that are not underlined, you have to write it entirely in this case.

1.) He used to could drink black coffee late at night.

2.) The lad maun coud muck the byre.

3.) She wad coud milk the kye gin she ettelt.

4.) We might could park over there.

5.) Lance may will want corn instead of potatoes.

6.) He'll should can come the morn.

7.) You should ought to make the rules clear.

8.) She'll can tent the bairn.

9.) We might will have time to eat something before we have to go.

10.) I may can get it out tomorrow.

11.) He used to wid let me up the brae.

12.) They will need to can drive a lorry to get that job.

\section{Task 3: Additional questions}

1.) How often do you use these types of underlined structures above?
A/ a lot
$\mathrm{B} /$ often
C/ occasionally
$\mathrm{D} /$ rarely
E/ never

2.) You write these types of underlined structures above:
A/ a lot
B/ often
C/ occasionally
$\mathrm{D} /$ rarely $\quad \mathrm{E} /$ never

3.) Do you have a name for these underlined structures?

4.) Can you cite a couple of places or circumstances in which you use these underlined structures? 
5.) What is Scots for you? Give me your personal definition of it (based on your own life experience)?

6.) Do you speak Scots?

Yes No

Do you write Scots?

Yes No

7.) What type(s) of dialect(s) of the Scots language do you use? Can you give the names of these varieties or dialects? Indicate those you speak and/or those you write and/or those in which you do both.

8.) Do you use some of the underlined structures in your Scots dialect(s)?

Yes No

Do you use some of the underlined structures in your Scottish English dialect(s)? Yes No

If yes, draw up a complete list of these structures you use.

9.) What is your oral frequency of use of the Scots dialect(s) in general?
A/ a lot
B/ often
$\mathrm{C} /$ occasionally
$\mathrm{D} /$ rarely $\mathrm{E} /$ never

10.) What is your written frequency of use of the Scots dialect(s) in general?
A/ a lot
B/ often
$\mathrm{C} /$ occasionally
$\mathrm{D} /$ rarely
$\mathrm{E} /$ never

11.) Where do you speak and/or write Scots?

12.) Where do you speak and/or write Scottish English?

13.) In your daily life, you use more:
A/ Scottish English dialect(s)
B/ Scots dialect(s)
C/ English English dialect(s) 